\title{
1. Accumulating human capital for sustainable development
}

Over the last half century, Korea successfully escaped from poverty and socio-economic instability to achieve remarkable economic growth and democracy. An average Korean lived on 2.3 dollars per day in the 1950s; she now earns about 60 dollars per day. Since 1960, the Korean economy has maintained a 6 percent annual growth rate of real GDP per capita, becoming the 13th largest economy in the world (Maddison Project, 2013). This achievement is regarded as a historic case of sustainable growth. While several factors contributed to this outstanding growth, there is emerging consensus that Korea's achievement of both sustained economic development and democracy is mainly due to its investment in people.

At its initial stage of development, Korea faced problems similar to most other developing countries. To escape from a vicious cycle of poverty, Korea had to overcome a legacy of antiquated traditions in education and training. Koreans had traditionally neglected vocational and technical training, owing partly to Confucianism, which praises scholars of the humanities and farmers while disregards professions in manufacturing and trade. Because parents encouraged their children to pursue academic education in colleges and hold white-collar jobs, industries lagged behind with few technicians, skilled workers, and blue-collar workers. To make matters worse, Japanese colonial rule prohibited Koreans from accumulating both physical and human capital for entrepreneurship in industrial sectors. The three years of the Korean War with the division of the Korean peninsula also devastated the economic and social infrastructure and fundamentals for economic growth.

Within a decade after establishing its first modern government in 1948, however, Korea successfully established a universal primary education despite the massive interruption caused by the Korean War, which began in 1950. Consequently, since the mid-1980s, most youngsters - more than 80 percent of each cohort - attended secondary schools, and since the mid-1990s, more than half of the high school graduates advanced to tertiary education. Today, Korea is renowned for its highest rate of higher education enrollment in the world.

As a result, the educational attainment of workers dramatically 


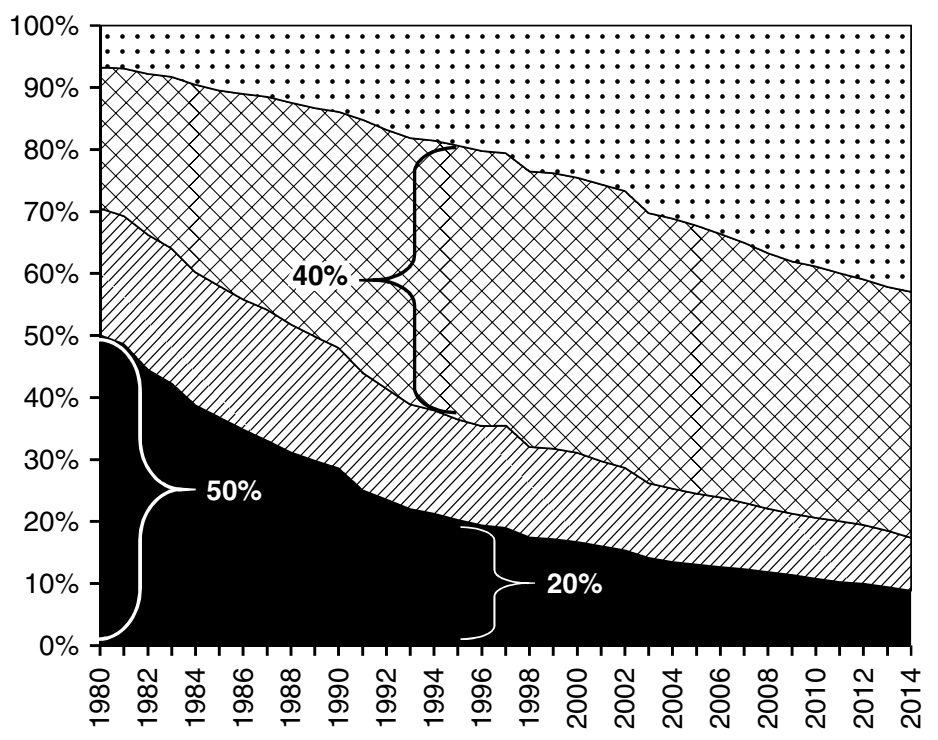

- Elementary School or Below $\square$ Junior High School Graduated $\square$ High School Graduated $\square$ College Graduated

Source: Statistics Korea, Economic Activity Census.

Figure 1.1 Educational attainment of workforce (1980-2010)

improved as shown in Figure 1.1. In 1980, the population share of primary education or lower was more than half, and that of college education or higher, only 6.7 percent. However, by 1987, the share of upper-secondary graduates (33.9 percent) exceeded that of elementary school graduates. Furthermore, in 2011, the population share of college graduates was 40.0 percent, exceeding that of high school graduates (39.8 percent). The number of researchers in Korea also grew rapidly after the 2000s. This rapid expansion of education among the public not only raised the personal income of Koreans but also enhanced the national productivity of Korea.

An important feature of Korea's educational development is that under such rapid expansion, the intellectual capacity of Korean students was enhanced significantly and effectively in response to the increasing opportunities for better education. This has been proven by the test performance of Korean students in international academic competitions. The results of the OECD's Programme for International Student Achievement (PISA) test since 2000 demonstrates that Korean students have consistently shown 
the highest level of performance along with Finland and Hong Kong (OECD, 2014b).

In addition to the effective enhancement of personal capacity, the following three key features characterize the process of Korea's educational development.

First, Korea's educational expansion promoted social mobility. Empirical evidence shows a low correlation between students' test score and their socio-economic status in Korea during the period of rapid educational expansion compared to other advanced countries. This means that Korea's education system has been more equitable compared to other advanced countries (OECD, 2014b) in that the expansion of education contributed to the promotion of equity in Korea. In short, Korea's economic and social development is characterized by a rapid and equity-promoting human capital accumulation.

Second, at the core of Korea's sustained growth was government-led skill development (ILO, 2010, p. 22). Vocational education and training contributed to a new culture of educating technicians indispensable for modernization and industrialization. The Korean government designed economic development policies for specific industries, and these industries were supported by manpower policies and vocational education. A national technical qualification system and extraordinary support for vocational education and training aligned to industry development prompted the training and upgrading of skilled workers. Moreover, industries were obliged by law to train and upgrade their employees.

With a successful universalization of primary education within a short period of time, Korea's secondary and tertiary education expanded sequentially under the government's control, which monitored the quality of both public and private education institutions through a centralized bureaucratic administration system. The government also regulated the number of students across different majors in colleges after carefully considering the supply and demand of manpower. This quality control of higher education played an important role in promoting the supply of an effective workforce to the labor market.

During the development stage, active participation of private schools and households supplemented the shortage of financial resources, which was later secured through legislations that earmarked a consistent share of the total internal tax revenue solely for education. Technical assistance and financial support from foreign countries also helped Korea strengthen its capacity for education and training.

Third, zeal for education was not limited to domestic education with many students and bureaucrats studying abroad. As early as the 1950s, a large number of students went abroad to study, and initially, only a few of 
them returned after graduation. However, they became a useful pool for a 'brain gain' in the beginning of the 1960s. Moreover, the Seoul National University (SNU) project, the Korea Institute of Science and Technology (KIST) project, and the Korea Advanced Institute of Science (KAIS) project all supported by the United States government accelerated this brain gain, which helped modernize Korea's higher education and upgrade the country's capacity in science and technology. Strong efforts to embody advanced technology in domestic human capital allowed Korea to quickly catch up to the advanced countries and to begin a dexterous improvement of technology, later leading to a rapid transition to technology-intensive industries. At the dawn of the knowledge-based global economy, however, Korea's capacity for innovation has been questioned.

In summary, the above characteristics of Korea's educational expansion (1) emphasizing equity in general education from primary to tertiary education, (2) linking education to the economy, particularly via vocational education and training, and (3) promoting 'brain gain,' especially for scientists and engineers - formed the three pillars of the nation's human capital accumulation. We will spell out the main features of the three pillars in more detail in the following discussion.

\section{EXPANDING EDUCATION WITH EQUITY}

How did Korea expand educational opportunities in such a short period? It is very difficult to single out any particular policy. In fact, there was no cure-all measure. However, one common feature in Korea's educational expansion was that the guidance and policies of the Korean government were met with an active participation of the Koreans. Rapid expansion of education with equity was possible through the judicious mix of top-down pushes by the government and bottom-up responses by the people.

The first task of the newly established modern government of Korea was to wage a war against illiteracy. Literacy is one of the key elements of economic development and social governance. Once people can read and write, they can learn from manuals at work places, understand prescription medicines, purchase products after reading and comparing advertisements, and compare political pledges to choose and vote for better leaders. That is, literacy can eliminate many root causes of poverty and can raise the standard of living. Furthermore, it can prompt self-efficacy and social participation.

During the colonial period, Japan forcibly imposed its language as official for Korea, depriving most Koreans of educational opportunities even at the elementary level. As a result, right after the country's liberation, the 
Table 1.1 Illiteracy rates (1945-1958)

\begin{tabular}{cccc}
\hline Year & Population above age 12 & Number of illiterate & Illiteracy rate \\
\hline 1945 & $10,253,138$ & $7,980,902$ & 77.8 \\
1948 & $13,087,405$ & $5,411,080$ & 41.3 \\
1953 & $12,269,739$ & $3,145,259$ & 25.6 \\
1954 & $12,269,739$ & $1,709,020$ & 13.9 \\
1955 & $12,269,739$ & $1,524,041$ & 12.5 \\
1956 & $13,911,678$ & $1,419,205$ & 10.2 \\
1957 & $13,713,873$ & $1,145,293$ & 8.3 \\
1958 & $13,713,873$ & 562,982 & 4.1 \\
\hline
\end{tabular}

Source: Kim, Y-H. (2015, p. 120).

Korean illiteracy rate was at a towering 80 percent (Table 1.1). The Korean government reinstated its mother tongue as the official language and pushed for a strong literacy education, employing a two-track approach of a mandatory education curriculum for students and a literacy education program for out-of-school adults.

In 1949, Korea enacted the National Education Law that established Citizenship Training Schools all over the country, particularly for adults in rural areas. The training schools were three-year elementary school programs for illiterate adults. Farmers were required to attend the school for at least 200 class-hours for a minimum of 70 days, an average of three hours per day. Since farmers are busy during the farming season, most of the classes opened off-season in winter. As a result, the illiteracy rate of 77.8 percent in 1945 dropped dramatically to 4.1 percent by 1958 .

The law also required every child to attend elementary school. However, during the serious three-year interruption of the Korean War, many parents were reluctant to send their children to school, and many families could not afford to pay tuition for all their children. Boys, usually the eldest, had the priority, while girls and other siblings were generally discouraged from obtaining formal schooling.

From 1954 to 1959, however, the Korean government actively implemented and strongly enforced mandatory schooling through the Six-year Compulsory Education Expansion Plan. Parents or guardians who did not send their children to schools were fined or punished. The plan targeted 90 percent enrollment of the elementary school-aged population by 1959 . The government allocated about 80 percent of the educational budget to achieve the compulsory elementary education. Furthermore, most of the foreign aid received for education was spent on repairing or building class- 
rooms. Nonetheless, there were still not enough classrooms and schools to accommodate all new students.

During this period, schools utilized 40 percent of classrooms for double or triple shifts per day ${ }^{1}$ with more than 100 students packed into small classrooms, particularly in the urban areas. To overcome the shortage of teachers, the government established temporary teacher training centers and 'Normal Schools' for training potential elementary school teachers. The graduates of the Normal Schools were granted teaching certificates after completing upper secondary school as were the graduates of high schools who completed an 18-week course at a training center. In 1961, all Normal Schools were upgraded to two-year teacher colleges, which between 1981 and 1984 were upgraded to four-year institutions known as the National Universities of Education (Kim and Han, 2002).

Elementary enrollment rate exceeded 90 percent in 1957 and reached 96.4 percent in 1959. Early universal elementary schooling laid the foundation for the growth of secondary education (Lee, Kim, and Adams, 2010, p. 71). Having every child achieve a basic education is not an easy task. There needed to be enough classrooms, teachers, textbooks, and the like. However, Korean people's hope and belief in schooling as the most important escape route for their children from ignorance and poverty were powerful driving forces in overcoming all the difficulties. That is, both the government's leading initiatives and the responding population's enthusiasm for learning to escape from poverty were equally important in achieving such a rapid and steady educational expansion.

After the successful installation of universal primary education, the Korean government moved to expand the next higher level of secondary, vocational, and tertiary educations sequentially. As shown in Figure 1.2, the jump in enrollment rate for each school level followed that for the preceding level. That is, the expansion of higher level education was implemented only after a sufficient expansion of the immediately lower level education. This sequential expansion of education was an important feature in building Korea's education system (Mingat, 1998; Patrinos, 2016). This made the transition process smooth and efficient, not only for educational expansion itself but also for the national development process in terms of balancing the supply and demand of labor market and human capital accumulation.

In particular, the enrollment rate of higher education was kept under control until the 1980s. This was possible due to a strong centralized

Schools operated two to four different class groups. Once morning class students left, another group of students attended an afternoon class in the same room. 


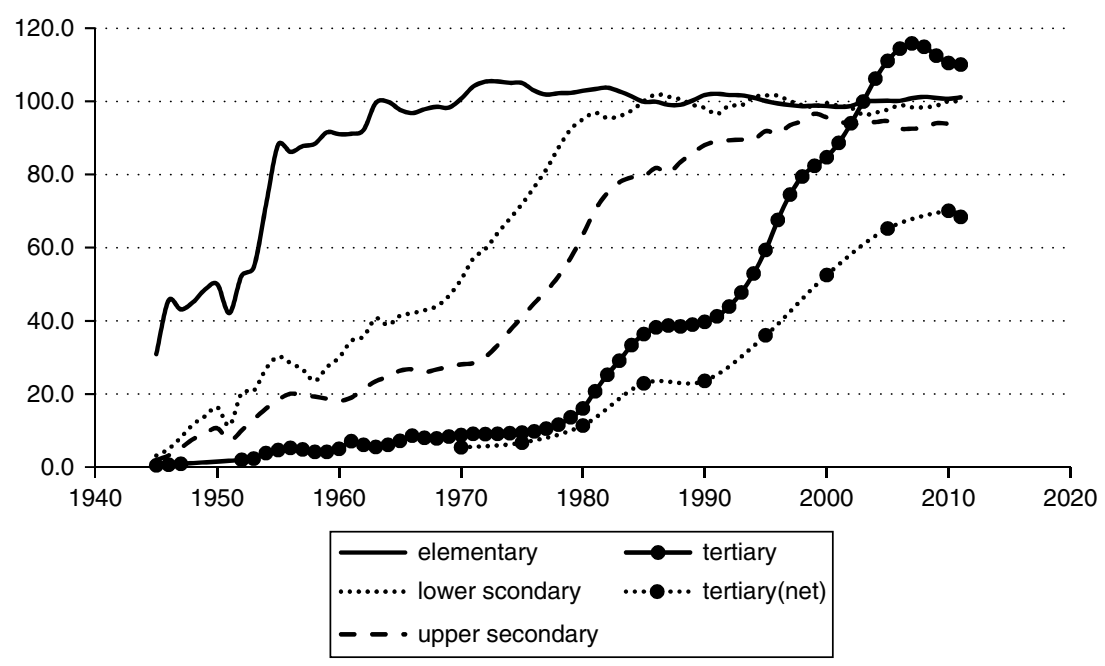

Notes:

Enrollment Rate $=$ (number of students in school) $/$ (number of school age population $) \mathrm{x}$ 100.

We calculated enrollment in four-year colleges and two-year colleges based on the National Statistical Office's standard on schooling age between 18 and 21. Other organizations such as the UNESCO define ages between 18 and 22 as schooling age, and at times they include graduate school students as part of schooling age. The enrollment rate at the tertiary level is higher than $100 \%$ in Korea not because there are adult learners who work and study at the same time but because there are many male students who return to school after their military draft. The net enrollment rate indicates the percentage of students at official schooling age who are actually enrolled in school.

Source: Statistical Yearbook of Education, various years by MOE and KEDI; UNESCO database.

\section{Figure 1.2 Enrollment rates (1948-2010)}

control system established in 1961 with the inauguration of President Park Chung-hee.

When the government initiated strong economic and industrial policies, national leaders were concerned that schools and universities might fail to supply a qualified workforce and hence built a centralized control system for individual schools including private schools. New enactments and regulations on admission, graduation, curriculum, teacher qualifications, and supervision were established, and the coordination mechanisms between education and industry were also institutionalized such as (1) an enrollment quota system for academic majors and universities, (2) a national skill qualification system, (3) and university-industry cooperation programs. During the 1960s while controlling new general high schools and 
higher education institutions, the Korean government strongly encouraged building new secondary schools and vocational schools. Furthermore, underperforming colleges were either closed or transformed into vocational institutions.

The Korean experience sheds light on the importance of balancing quantitative expansion in education with qualitatively effective improvement. Unilateral expansion without consideration for socio-economic demand can undermine the quality and impact of education and social sustainability. As schools and colleges were strongly controlled by Korea's central government, major changes were enforced by the government's decisions, most of which were announced unexpectedly. However, it is noteworthy that such changes and reforms appropriately reflected the evolving economic and social demand for education.

The increasing enrollment in primary education in the 1950s increased the demand for secondary education, making entrance into middle school and high school highly competitive. Parents who could afford private tutors paid extra money for their children's preparation for middle school entrance examinations in the 1960s. Similar competition and private tutoring occurred when these students advanced to high schools later in the 1960s and 1970s. To relieve the burden of private tutoring and level the playing field for admission, the government replaced the entrance examination system administered by individual schools with a lottery assignment system for middle schools in 1969 and for general high schools in $1974 .^{2}$

In addition to randomly assigning students to schools within a school district, the government equalized schools, including private ones, in terms of teacher quality, finance, facilities, curriculum, and the like. This equalization policy furthered the enrollment in secondary schools. More

2 To ease the competition for general high schools, the educational authorities replaced the entrance examinations administered by individual schools with national or province-wide ones. The policy decreed that students who passed the test would be assigned to schools within their school districts by lottery. This policy was first introduced in Seoul in 1974 and later expanded to other metropolitan and large cities. In addition to equalizing the socioeconomic background of students, the government tried to equalize curriculum, facilities, finances, and teachers and staff, who were required to be transferred to other schools every five years (Lee, Kim, and Adams, 2010). Various regulations on education administration, school management, and personnel operations were enacted by the central government and strictly implemented by bureaucratic controls. On the one hand, the policy was hailed as timely and appropriate, saving students from the heavy pressure of examinations and expanding the opportunity of secondary schooling. On the other hand, the abrupt change concerned others in that the 'one-size-fits-all' policy and bureaucratic control may harm diversity and creativity of schools in the long run. Meanwhile, this rule did not apply to vocational high schools. Rather, in the 1970s, the government strategically selected some of technical high schools and supported their facilities and scholarship, which was to provide the industries with skilled technicians within short time periods. 


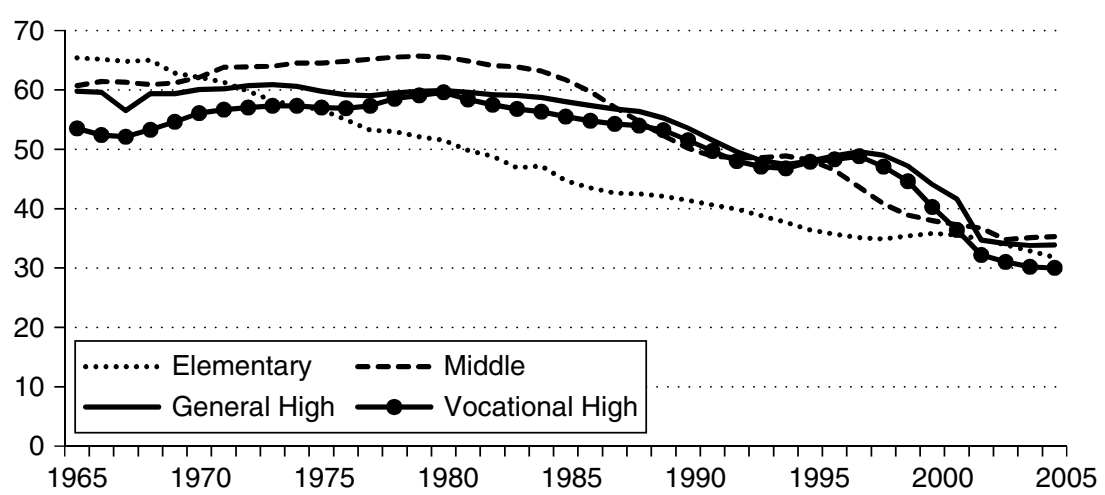

Source: MOE and KEDI, 1965-2005.

Figure 1.3 Average number of students per class in elementary and secondary education (1965-2005)

than 90 percent of the elementary graduates directly advanced to middle schools since 1979, and the same ratio of middle school graduates went on to high schools since 1985. Universalization of secondary education guaranteed access to education for the public, which made the Korean society more equitable in terms of opportunity and the Korean economy more abundant in human capital.

To some extent, however, this rapid expansion of opportunity was achieved at the expense of the general quality of education. Classrooms were over-crowded and teachers were in charge of more students compared to other countries. For example, Figure 1.3 shows that in the $1960 \mathrm{~s}$, the average number of students per class was around 60 (65.4 in elementary schools, 60.7 in middle schools, and 59.8 in general high schools). Figure 1.4 shows that the number of students per teacher was 62.4 in elementary schools, 39.4 in middle schools, and 32.2 in general high schools. Both Figures 1.3 and 1.4 show that those ratios have decreased over time but are still higher than those of advanced countries.

Despite large class size, Korean students have shown very high academic performance thanks to high expectations and strong commitment of parents, and high spending on private tutoring. However, large class sizes may have had the negative effect of neglecting deep and creative learning for students. Multiple-choice tests became inevitable due to large class sizes, and consequently learning methods were mainly based on rote memorization.

The government gradually expanded higher education, particularly through junior colleges, in response to the increasing industrial demand for 


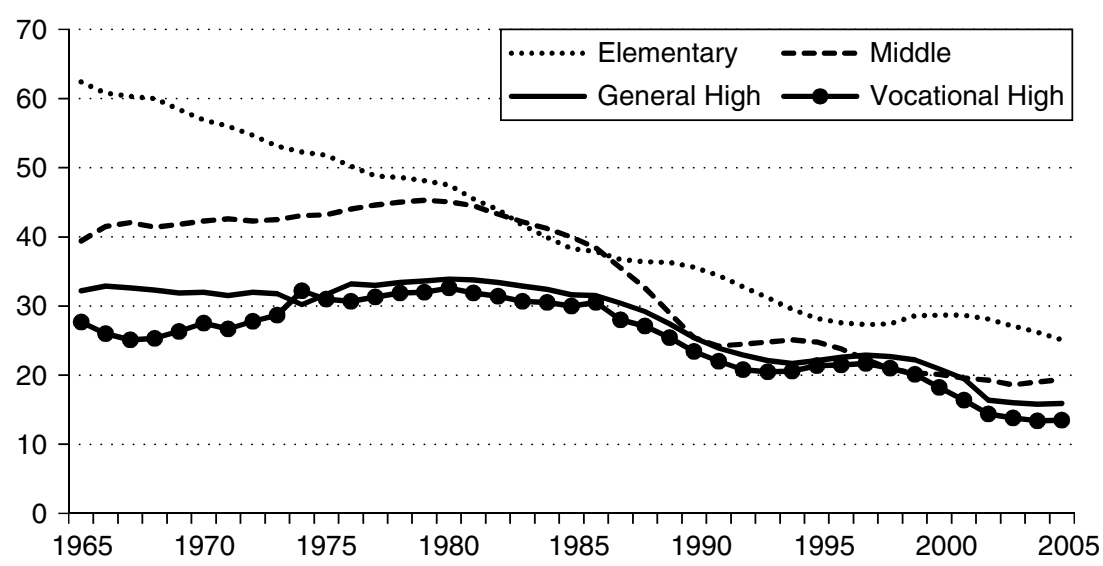

Source: Same as of Figure 1.3.

Figure 1.4 Average number of students per teacher in elementary and secondary education (1965-2005)

advanced technicians in the late 1970s. However, before the door to higher education was widened, an increased number of high school graduates faced fierce competition in college admissions. Expensive private tutoring costs remained as a hurdle to the expansion of opportunities for higher education, hence to social equity. Education policy makers and political leaders felt pressured to tackle this social problem.

At the beginning of a new phase of economic development in the 1980s, the Korean economy needed to nurture more globally competitive scientists and engineers by expanding higher education. In July 1980, the new military government endorsed comprehensive education reform, including the replacement of the graduation quota system with a freshmen quota system. In the academic year of 1981, universities admitted 30 percent more new freshmen than graduation quota, and the total number of students in tertiary education jumped compared to the previous year. Policies also banned private tutoring and abolished written tests administered by individual universities to relieve students and families from the heavy burden of study and extra educational spending. As a result, as shown in Figure 1.2, the net enrollment rate in tertiary education jumped from 6.7 percent in 1975 to 11.4 percent in 1980 and to 22.9 percent in 1985 . The deregulation of higher education later in the 1990s raised this rate to 52.5 percent in 2000, which accomplished the universalization of tertiary education.

The expansion of higher education opportunities in response to the 


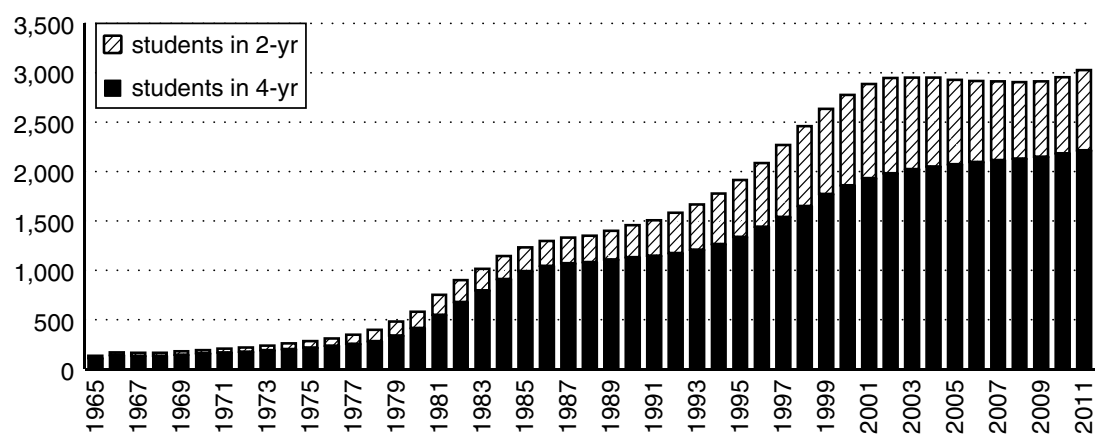

Note: Scale in thousands.

Source: Same as of Figure 1.3.

Figure 1.5 Number of students in higher education (1965-2011)

increasing economic and social demands in the 1980s contributed to economic growth and social mobility. Moreover, universalization of tertiary education contributed to sound monitoring of political powers and encouraged democratic participation in community activities, which were critical for sustainable development. Korea's democratization process including the non-violent transition of governments in 1988 and the launch of a civilian government in 1993 would not have been possible without the engagement of this increasing number of intellectuals through universalization of tertiary education.

Figures 1.5 and 1.6 display the number of college students and the growth rates over the last 60 years, respectively. The total number of students in higher education increased to more than 500,000 in 1980, continued to rise to almost 1.5 million in 1990, and reached almost 3 million in 2002, stagnating thereafter. Due to the decreasing birth rate in Korea, Korea's youth population has shrunk drastically in recent years, and the government started to push for strong restructuring of universities in 2009 to accommodate such demographic changes, once the college enrollment rate stabilized.

Despite the positive contributions of higher education expansion, the rising concern has been the undesirable consequences for human capital accumulation from the rapid increase in college enrollment rates among Korean students as the expansion was concentrated among low quality universities, particularly after the 1990s. We will discuss this critical issue separately in the following chapter.

Since the initial stage of development, the public resource was insuf- 


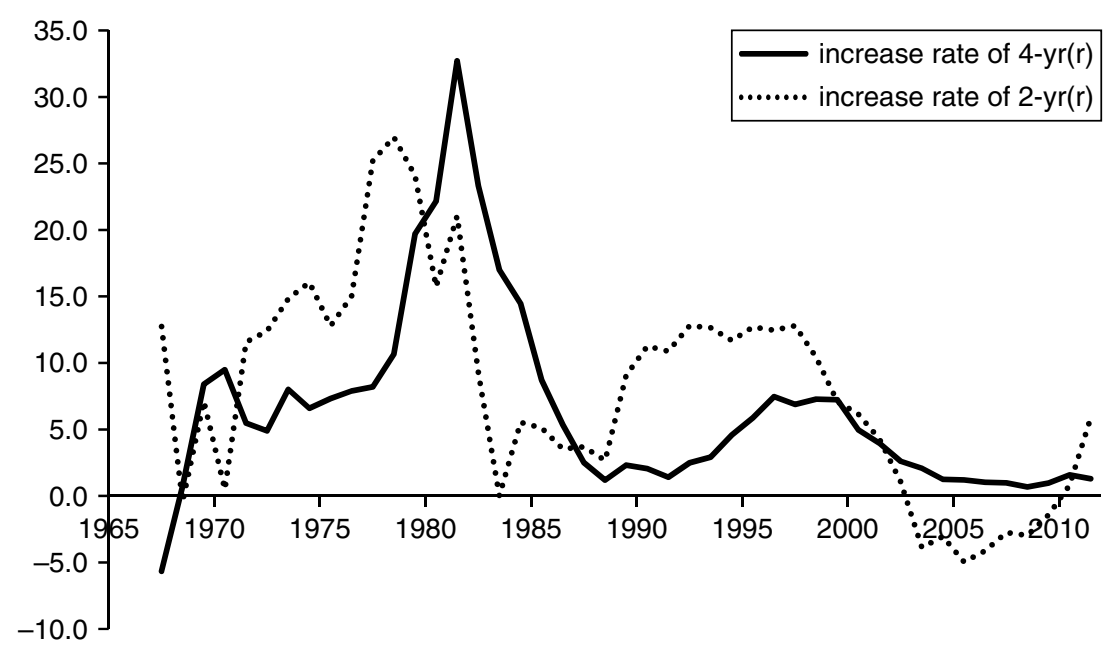

Note: Scale in percentage terms.

Source: Same as of Figure 1.3.

Figure 1.6 Rate of increase of students in higher education (1965-2011)

ficient for free teaching and training for everyone all at once. The available resource of the Korean government in the 1950s and 1960s was not even enough to provide free primary education, not to mention secondary and tertiary educations. Therefore, private households and donors shared the financial burden. Many people donated their lands and assets to build schools, especially middle schools, high schools, and colleges. While the government concentrated on the expansion of elementary schooling, the private sector filled the gap for secondary school and above. In fact, the number of private schools built from 1955 to 1967 was equal to the number of public schools built during the same period.

The repressed enthusiasm for learning and teaching during the colonial rule led to a national wave of private education right after the country's liberation. During the 1946 to 1960 period, 32 new private universities were established, 10 in 1946 and 18 before 1950. The government also encouraged this movement by giving favors to the landowners who used their land to found private schools. Owing to the active donation from private sectors, 74 percent of college students and 59 percent of high school students enrolled in private schools in 1980 as displayed in Figure 1.7.

Private households, another important stakeholder in education, also 


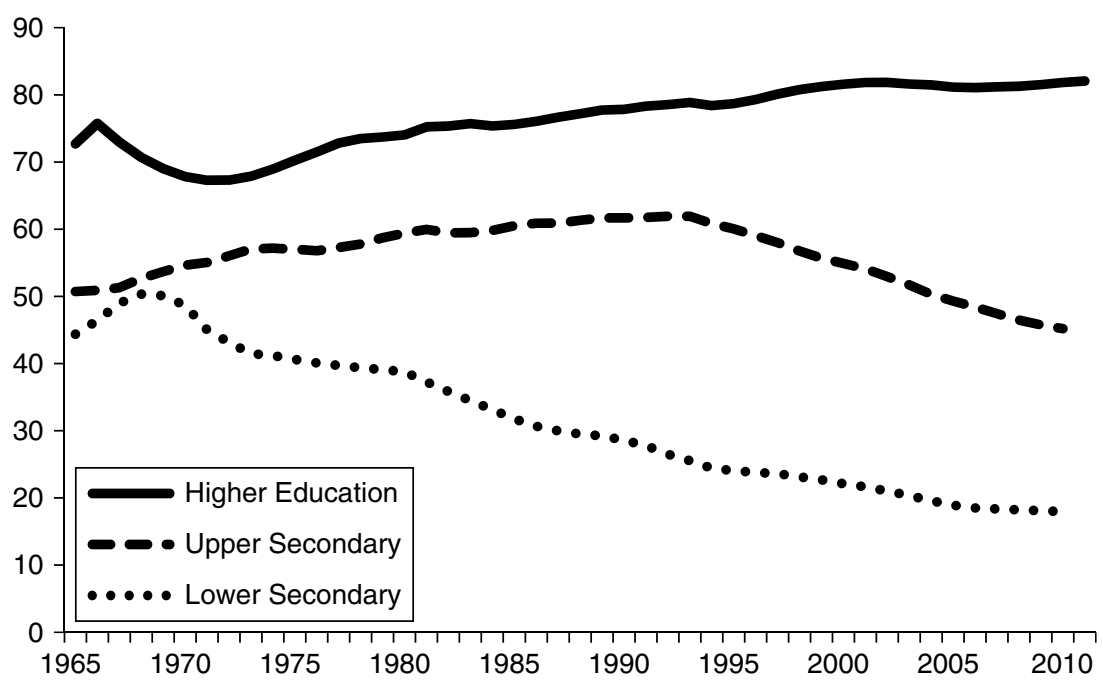

Source: Same as of Figure 1.3.

Figure 1.7 Ratio of students enrolled in private schools

played an important role by sharing the burden of public schooling expenses such as tuition fees, parent and teacher associations, textbooks, and special activities. That is, the private sector supplemented the insufficient public finance. Including the money spent on private tutoring, the total amount of private household expenditure was equivalent to that of the public education budget.

Compared to the level of economic development, Koreans have invested a huge amount of resource towards education. More than 5 percent of the total GDP was spent on education by the government and households since the 1960s. In 2008, in addition to the government's education budget of 4.5 percent of the GDP, private households spent 2 percent of the GDP on school tuition and another 2 percent on private tutoring.

Evaluating this private sector contribution, we cannot underestimate the role of land reforms, which began in 1950, on human capital accumulation. Due to the restrictions on land ownership for big landlords, tenant farmers were able to become independent farmers with increased income. As their wealth increased, they were able to send more of their children to schools and spent more on education than before. In other words, land reform endowed people with more equal educational opportunities as one of the most important channels of social mobility. In addition, the government gave favors to the land owned by private school foundations to encourage 
landowners to establish new schools. Therefore, land reform contributed to human capital development in many ways.

The Korean government effectively utilized financial and human resources from foreign countries to set up the basic infrastructure and develop policy for sustainable development. Foreign aid and technical assistance provided the solution to the scarce domestic financial resources and the weak capacity of education sector. According to McGinn et al. (1980), the Korean government received more than 100 million USD as official foreign aid for education during the 1952 to 1963 period and allocated a huge portion of 70 million USD for building and repairing classrooms. The second largest spending using foreign aid was 19 million USD invested in the leading national university, the Seoul National University and other higher education institutions. To transfer knowledge from the United States, experts from the U.S. were invited to stay in Korea to provide consultation. Many Korean students were sent to study abroad and became faculty members and government officials after returning home. Remaining foreign aid funding was used for teacher education in partnership with the George Peabody Teacher College (9 million USD) and for purchasing materials and equipment for vocational education (7.8 million USD).

In terms of utilizing foreign resources for investment projects, the Korean government relied on loans rather than foreign aid grants since the 1960s. The borrowing for human resource investment was not insignificant either as from 1959 to $1999,4.6$ percent of public loans were spent on human capital investment such as education, R\&D, and health expenditures. In the education sector, foreign resources were used to modernize vocational and technical education and support higher education. Spending on building training facilities and purchasing $R \& D$ equipment accounted for 94 percent of the total educational loan (Lee, K.K., 2004). Instead of relying on direct subsidies or arranging ineffective projects for government consumption, the government focused on investment in educational infrastructure and trainings in line with promoting industrialization and human capital accumulation.

Meanwhile, to secure the necessary domestic finance for education in addition to foreign resources, the Educational Grant Act was passed in 1971, requiring that a certain proportion of the total national tax revenue be automatically saved and transferred to the education budget. This was possible due to a more stable domestic public-financing environment and led to the central government providing the largest share of funding for elementary and secondary schooling. The educational saving rate of the national internal tax was 12.98 percent in 1971, substantially increasing to 20.27 percent in 2010 . Korea achieved the world's fastest educational 
expansion in the last half century not owing solely to the effective enforcement of education policies but also to the strong financial commitment of the Korean government.

Rapid economic growth with an emphasis on openness and equity and the steady decline in birth rates are closely related to the increase in human capital investment. According to human capital theory and endogenous growth theory, human capital is the engine of economic growth, and the fuel of this growth engine is the rate of return of human capital investment promoted by an efficient market (Lucas, 1988; Romer, 1990; Ehrlich, 2007). In this context, Korea's development of an efficient market economy also contributed to the country's educational expansion.

Ju-Ho Lee (2004) points out that openness and equity, two major characteristics of Korea's economic development, contributed to educational expansion. The outward-oriented economy allowed those with higher education to receive higher wages and secure better jobs, and relatively equal income distribution made education affordable to most people. Through this virtuous cycle of economic growth and human capital accumulation, Korea was able to achieve rapid economic growth simultaneously with rapid educational expansion (Lee et al., 2012a; Suri, Boozer, and Ranis, 2010).

Another important link to educational expansion is the relationship between education and birth rates. Unlike the Malthusian prediction that an increase in household income is followed by an increase in birth rates, Becker, Murphy, and Tamura (1990) focus on the fact that while household income increased in the Western countries, birth rates decreased and contributed to human capital accumulation. According to their argument, for a country with abundant human capital, social welfare becomes greater when parents' investment focus on improving the living quality of an individual child rather than increasing the number of children, and thus birth rates will decrease and human capital investment will increase. Korea's average total fertility rate was 6.0 persons in 1960, 4.07 persons in 1973, 3.0 persons in 1976, 2.06 persons in 1983, and 1.53 persons in 1987. It decreased even further to 1.24 persons in 2011. Currently, Korea's fertility rate is the lowest along with Hungary among the OECD countries (with an average total fertility rate of 1.70). Korea's unique case of such a drastic decline in birth rates is closely related to its rapid educational expansion.

\section{LINKING EDUCATION TO ECONOMY}

During the early stage of Korean development, the successful achievement of universal primary education provided light manufacturing industries 
with an adequate workforce. As the Korean economy developed further, however, the demand for a new mass of skilled workers surged as the focus shifted from labor-intensive light industries to technology-cum-capitalintensive heavy industries. However, most families and children looked down upon vocational education and technical training, partly due to the deeply-rooted tradition of Confucianism.

Of course, Confucianism has positively contributed to Korea's human capital accumulation through its emphasis on general learning, which led parents to strongly motivate their children to study hard and made policy makers place high priority on education. While retaining Confucian virtues, Korea made substantial efforts to adapt its education to economic transformation by supplying a better labor force, matching the demand from rapid industrialization (Ashton et al., 2002; Green et al., 1999).

Nonetheless, overcoming the long-standing prejudice against vocational and technical training was not easy. Initially, the prejudice was strong enough to prevent the poor agricultural country from industrialization. As a result, until the late 1950s and early 1960s, industries lacked skilled workers and faced difficulties in running their businesses; at the same time, the unemployment of college graduates caused a major social problem. At first, government policies promoted vocational education at elementary schools while newly established Comprehensive High Schools offered preparatory courses for both college entrance and vocational training. Regardless of these efforts, most students wanted to advance to college, and such training courses were not operated successfully.

To resolve this problem, the Ministry of Science and Technology prepared a critical report in 1972 that addressed the inherent problems of skill development schemes and qualification systems. After examining the education system, the report identified the following problems for Korea's skill development at the time: (1) the dearth of skills education for primary school graduates who do not advance to secondary education, (2) the lack of practical ways to utilize secondary school graduates as professional technicians, (3) the unclear function and role of vocational high schools, and (4) the need to revise the system to allow for practical education and field experience in college curriculums and facilities (Hong, Jeon, and Kim, 2013; MOST, 1972).

When the Economic Planning Board announced the Five-year Economic Development Plan for the 1962-1997 period, each ministry prepared detailed action plans to implement it. Each Economic Development Plan was supported by a Manpower Development Plan and the associated policies of labor supply and vocational education. The Ministry of Science and Technology (MOST) and the Ministry of Education (MOE) forecasted the supply and demand of craftsmen, technicians, and engineers in every 
industry and prepared a supply plan to meet those needs by controlling the number of high school and college graduates. The progress was monitored monthly by all the stakeholders including government officials, businessmen, and other experts. This monitoring and coordinating mechanism was as important as the plans themselves.

The first Manpower Development Plan in 1962 emphasized increasing the supply of engineers by raising the freshmen quota in science and engineering departments at universities as well as technical high schools. It also included in-plant vocational training and technical manpower training in the military. The second plan in 1967 curbed the quantitative expansion of colleges and general high schools while focusing on strengthening the quality of education in science and technology and expanding vocational training.

The third and fourth Manpower Development Plans during the heavy and chemical industrialization period of the 1970s focused on the supply of skilled workers through higher education. The third plan emphasized university and graduate school education, reinforcing skill-learning systems and securing specialized manpower in medicine, teaching, and marine technology. The fourth plan in 1977 highlighted graduate schools to foster scientists, 'specialized universities' to secure engineers in heavy and chemical industry, technical high schools to promote middle-level engineers, and technical universities to play an important role in development and improved the 'National Technical Qualifications System.'

In the 1980s, to meet the demands of technology-intensive industries, Manpower Development Plans emphasized securing human capital with the capacity to adapt to industrial changes. The government planned to increase overseas technical training in advanced economies and to invite more experts from abroad. The sixth plan aimed to foster and secure highlevel scientists and technicians who would lead technical innovations and to expand the research labor force with doctorate degrees in engineering. At the beginning of the knowledge-based economy in the 1990s, universities were given more autonomy to decide their student distributions across different majors and to develop corresponding strategies (Lee and Hong, 2014, pp.45-48; Kim, Y.T., 2002).

The 'freshmen quota system' was a unique tool for coordinating higher education with the industrial labor demands in Korea. After reviewing the applications of each higher education institution for admission quotas, the Ministry of Education determined the number of freshmen students allowed to enrol in each department at each university. In principle, the Ministry of Education considered the demands from industries in general, especially those from the strategically targeted industries, the facilities and regional conditions of educational institutions, and other factors in 
consultation with other ministries to finalize the number of students. ${ }^{3}$ The Special Act on Education prepared by an ad hoc military ruling committee in 1961 authorized the government to adjust the number of classes and students of public as well as private colleges. This governmental control over higher education was confirmed with a presidential decree on student quota of higher education in 1966. This control system lasted more than 20 years until being relaxed in 1990 .

To attract young people to the fields of modern science and engineering and to raise sufficient technical personnel, the Korean government encouraged young technicians to participate in international skill competitions since 1967 with the government celebrating with national ceremonies upon their return. Medalists were hailed as heroes, marching in parades from the airport to the capital city, welcomed by the president. When Korean technicians achieved the top honor in 1977, the president himself congratulated them with the following address:

Your top score at this critical juncture where we are pursuing an industry-driven economy has certainly boosted our morale in the hope of joining the ranks of advanced industrialized nations in the near future. In the past, there were times when our athletes took home medals from international sports competitions such as the Olympics. But I think the fact that young Koreans showcased their talents and abilities in the heavy and chemical industry sector at the World Skills Competitions bears a major significance. (Maeil Kyungjie Shinmun, July 19, 1977; Hong et al., 2013: p. 34)

The trophies won at the competitions were mainly due to the new vocational high schools, which were built with state-of-the-art equipment financed with foreign loans. A portion of the students at vocational schools benefited from full scholarships, dormitory residence, and stipends. The presidential office at the Blue House was the strongest supporter of vocational education with the president frequently visiting these

3 The main purpose of the enrollment quota system was to guarantee minimum quality and to check the reckless expansion of higher education in the early development stage. The Ministry of Education (MOE) set the enrollment quota at the level of individual departments of universities based on their capacities of facilities and faculties. Individual institutions made yearly requests of enrollment quota adjustment based on the guidelines prepared by the Ministry of Education, which consulted with the related ministries and organizations about the future demands of human resources. Universities and colleges had to submit documents to explain the reasons for new enrollment quota, current conditions of faculties, and the plans of new recruitments and constructions. After reviewing the applications, the MOE announced enrollment quota at college and department levels according to the 'Ordinance of the HEEQ' passed in 1965. In addition, to prevent unpermitted admission and graduation, a degree registration system was adopted from 1967 requiring universities and colleges to submit their lists of degree earners to the MOE (Kim, Y.H., 2000). This program contributed to the quality improvement of higher education but also created needless bureaucracy. 
schools to encourage students and teachers. He also awarded presidential scholarships to those who acquired precision licenses during their school days.

To strengthen the link between educational institutions and industries, the Industrial Education Promotion Act was passed in 1963. The legislature included provisions to promote vocational education by central and local governments who provided the expenses for experiments, practical education and qualification of teachers, and scholarships. The act also included the establishment of the Central Industrial Education Council to adopt the opinions of industry sector for curriculums with the government inviting experts from industries to design the curriculums (Lee and Hong, 2014).

The government also initiated the Science \& Technology Education Promotion Plan (1967-1971) for vocational and educational training. The plan was designed to foster scientific thinking and creativity, to promote science in daily life, to expedite technology innovation and scientific inventions, and to cultivate the abilities and qualities needed in productive technicians. Major contents of the plan included expanding industrial vocational high schools to increase the supply of technical workforce, increasing the enrollment quota of universities in science and engineering, establishing industrial-related majors in agricultural high schools, enacting guidelines for experiments and practical education, and promoting industry-academic cooperation (Lee and Hong, 2014).

One of the most ambitious projects for strengthening vocational high schools was the Specialization Initiatives for Technical High Schools (SITHS) designed by the Blue House, which aimed at supporting the heavy and chemical industrialization policies of the 1970s. The quality of vocational schools in those days was insufficient to nurture the skills needed at industrial work sites. However, policy makers found it difficult to enhance the quality of vocational schools all at once. Thus, the government adopted a 'selection-and-concentration' approach rather than a universal one-size-fits-all approach. With limited time and financial resources, the government strategically invested resources only in a small number of institutions to create tangible outcomes with a high chance of success.

Starting in 1973, the SITHS divided technical high schools into four categories: 'mechanical technical high schools,' 'experimental schools,' 'specialized schools,' and 'general high schools.' Each type had different educational goals and specialized curriculums. For example, mechanical technical high schools aimed to foster precision workers who were desperately needed for machinery and defense industries. The goal of specialized technical high schools was to nurture skilled technicians in the fields of electronics, chemicals, construction, iron, and rail- 


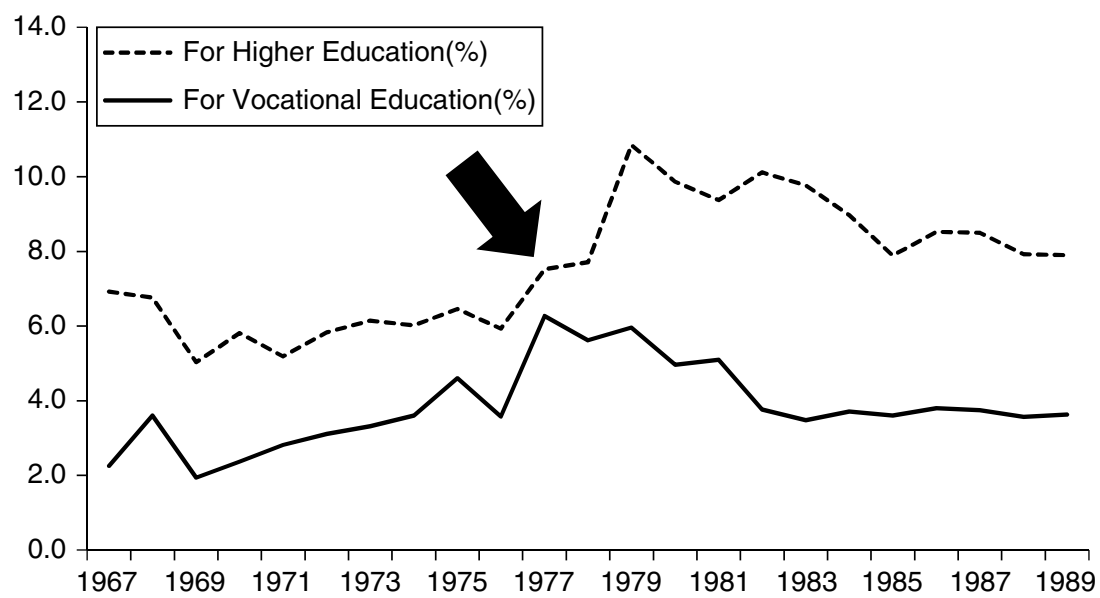

Note: Share of government expenditure for higher education does not include the special accounts of national university hospitals and faculty investment at the Seoul National University.

Source: MOE and KEDI, various years.

Figure 1.8 Share of government expenditure on vocational education versus higher education (1967-1989)

road. Experimental technical high schools trained special workers who obtained certain technical certificates to work overseas. ${ }^{4}$ At least one experimental high school was built in each province to serve as a model of exemplary school management with the hope that their management practice would spread to other general technical high schools. General technical high schools were given the responsibility of fostering certified technicians needed in general industrial sectors depending on the local conditions (Kim, Y.C., 1992; Kim, Y-H., 2015; Kim, Y.T., 2002; Lee and Hong, 2014, p. 74).

In 1977, government spending on vocational and technical education had almost reached that on higher education. Figure 1.8 reveals that substantial financial resources were poured into vocational high schools through the SITHS in the peak years of the industrial policy towards heavy and chemical industries. Since then, the gap between the budget spending

4 The skilled workers trained to work overseas greatly contributed to the Korean economy through remittances they sent back mainly from construction sites in East Asia as well as through the human capital they accumulated from international experience. 
on vocational education and higher education widened until the Meister High School Initiative.

Another important tool in promoting vocational and technical training was the establishment of the National Technical Qualification System (NTQS) in 1973. The Ministry of Science and Technology devised a national technical qualification system that could empower technical talents to utilize them in real industrial fields.

The National Technical Qualification System required all students at technical colleges and technical high schools and vocational trainees to take qualification examinations before graduation. The students who passed the qualification examinations were given priority in the job market. The engineers and technicians who acquired the highest level of qualification, such as Professional Engineer or Master Craftsman were considered on par with academic PhDs. By granting such economic and social favors to the NTQS certificate holders, this system weakened the deeply rooted disdain for technical occupations. The new skills standard required in such major fields like heavy and chemical industries transformed vocational education and training programs and consequently, influenced the quality and social status of technical manpower (Hong, Jeon, and Kim, 2013, pp. 66-69). Table 1.2 summarizes the different stages of the qualification system.

Upgrading the skills of the existing employees in industrial fields was another very important issue. From 1967, companies and businesses were asked to train their employees with government subsidies through the Vocational Training Act. This new law stated the qualification and training of instructors and included the building of public training institutes and in-company training facilities. Owing to this new scheme of vocational training, the number of training recipients increased by threefold from 10,000 in 1967 to 30,000 in 1970 . However, both public vocational training and in-plant vocational training of private companies heavily relied on government subsidies, which undermined their sustainability (Lee, K.W., 2005; Ra and Kang, 2012).

To tackle the shortage of financial resources and technical expertise, the government set up vocational training centers using grants from Germany (1971), Japan (1976), and Belgium (1976) and loans from the Asian Development Bank (5 centers, 1973-1976) and the World Bank (15 centers, 1977-1980) (Ra and Kang, 2012, pp. 36-39). These institutions were utilized not only for training workers but also for training instructors and developing training curricula.

The importance of in-plant training of workers and the limited public financial resources led to another pilot policy, the Vocational Training Special Measures Act, which made training mandatory and ended 


\section{Table 1.2 Changes in the Technical Qualification System}

\begin{tabular}{|c|c|c|}
\hline Stage & TVET & $\begin{array}{l}\text { National Technical } \\
\text { Qualification System }\end{array}$ \\
\hline $\begin{array}{l}\text { Before NTQ } \\
(1945 \sim 1972)\end{array}$ & $\begin{array}{ll}- & \text { Fostering technicians } \\
- & \text { Infrastructure for } \\
\text { technical training } \\
\text { (vocational training } \\
\text { centers by aid and loans) }\end{array}$ & $\begin{array}{ll}\text { - } & \text { License system by individual } \\
\text { industry acts } \\
\text { - } & \text { Introduction of certified } \\
\text { technician system } \\
-\quad \text { Promotion of skilled } \\
\text { personnel assisting certified } \\
\text { technicians }\end{array}$ \\
\hline $\begin{array}{l}\text { Introduction } \\
\text { of NTQ } \\
(1973 \sim 1981)\end{array}$ & $\begin{array}{l}\text { Expanding technical } \\
\text { high schools, technical } \\
\text { skills universities and } 24 \\
\text { public training centers } \\
-\quad \text { Operating national } \\
\text { skills competition and } \\
\text { participating in the } \\
\text { World Skills Olympics }\end{array}$ & 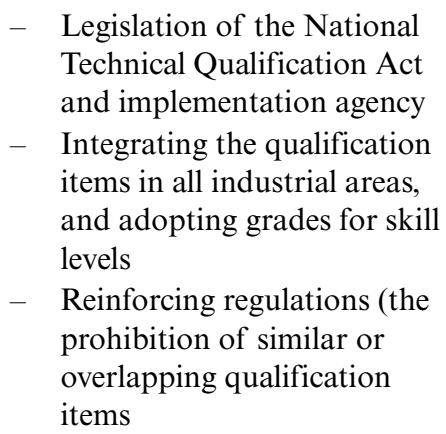 \\
\hline $\begin{array}{l}\text { Development } \\
\text { of NTQ } \\
(1982 \sim 1997)\end{array}$ & 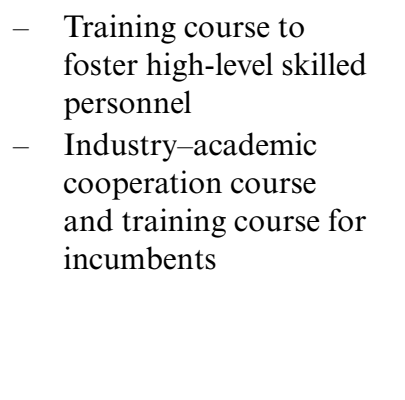 & 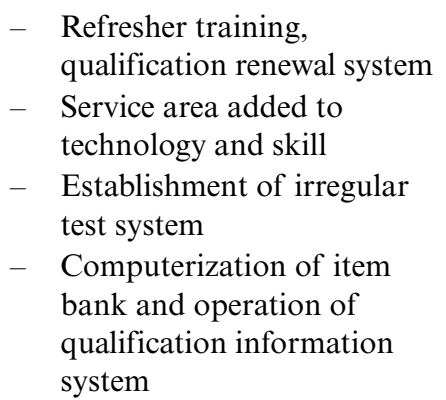 \\
\hline $\begin{array}{l}\text { Maturity } \\
\text { of NTQ } \\
(1998 \sim)\end{array}$ & 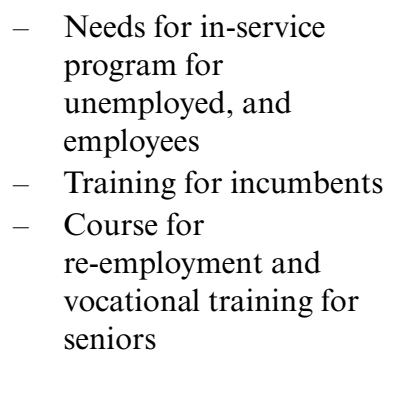 & $\begin{array}{ll}- & \text { Reorganization of 5-grade } \\
\text { system } \\
- & \text { Diversification of testing } \\
& \text { techniques } \\
- & \text { Easing qualifications for } \\
& \text { exam } \\
- & \text { New qualification items in } \\
& \text { service area } \\
- & \text { Commissioned tests for } \\
& \text { specialized items }\end{array}$ \\
\hline
\end{tabular}

Source: Park et al. (2012). 
government subsidies for training at private companies. ${ }^{5}$ The aim of the new measure was to strengthen employers' roles in training their own workers who would supply the necessary skills upon need.

The merger of the Vocational Training Act and the Vocational Training Special Measures Act into the Basic Vocational Training Act in 1976 reinforced the obligation of enterprises. The scope was extended to those with 300 employees or more, and the government set up the required number of trainees for each company across different industries each year, reflecting the demand for skilled workers within 10 percent of the total workers in the business. Under this scheme, enterprises could pay training levies instead of complying with the obligation of providing in-plant training. In 1978, about 70 percent of relevant companies operated in-plant programs, while the rest chose to pay levies ( $\mathrm{Ra}$ and Kang, 2012, pp. 32-34). However, the obligation of mandatory training was soon considered as an excessive regulation that would negatively affect businesses, resulting in more enterprises choosing to pay levies instead. By 1986, two-thirds of the enterprises that were supposed to provide in-plant training chose to pay training levies (Lee, K.W., 2005). ${ }^{6}$

The new business environments of the 1990s under the trends of globalization and knowledge-based economy changed the perspectives of government and enterprises on skill development. The Industrial Manpower Supply and Skills Development Restructuring Plan, drafted by the civilian government in 1994, called for voluntary training programs for private enterprises, which the government aimed to induce through an incentive system. The plan was followed by the introduction of the Employment Insurance System in 1995, which removed the mandatory obligation of in-plant vocational training and incorporated vocational skill development as part of an employment insurance system. Furthermore, the focus on skill development shifted from training a new skilled workforce to upgrading incumbent workers to support their 'lifelong skills' development. The new system was similar to the training levy system in that the obligation to pay vocational training levies was imposed on all enterprises but different in the sense that all enterprises had to pay

5 This applied on a pilot basis until the end of 1976 to enterprises employing 500 or more workers in six industries: mining, manufacturing, electricity, gas and water supply, construction, transportation, storage and communications, and services (Ra and Kang, 2012).

6 Many developing countries in Latin America, which implemented a training levy system, set up independent public vocational training agencies using the money collected from training levies. However, their lack of financial independence prevented them from responding flexibly to enterprises' demands to provide training courses, instructors, locations, and equipment, thereby exposing their weaknesses such as low training practicality and inefficiency (Ra and Kang, 2012, p. 43). 
the levies first and then the levies were refunded upon their provision of training (Ra and Kang, 2012, pp. 46-47).

With the legislation of the Workers Vocational Training Promotion Act in 1997 and the Workers Skills Development Act in 2004, the vocational skills development system in Korea evolved to accommodate the needs of workers and their changing working conditions. Table 1.3 summarizes the major policies behind the evolution of Korea's vocational training system from the 1960s to the 2000s that we have discussed so far.

The strong support for vocational education fostered many talented students, especially from underprivileged families and rural areas and opened up new career paths for technicians. It also played a very important role during the early industrialization period by supplying the necessary skills for manufacturing sectors including heavy industries. Rewarded by stable job security and salaries, technical workers formed the middle class in the Korean society (Ryu and Kim, 2011). In addition, the national efforts to respect technicians and to boost vocational education and training contributed to changing the mindset of the Korean people who previously looked down on such practical education.

\section{PROMOTING BRAIN GAIN}

At the initial stage of development, the Korean society faced a severe problem of 'brain drain' as a large number of people left to study abroad. During the 1953 to 1967 period, 7,958 people went abroad for higher education, which was about 6.4 percent of the students who enrolled at higher education institutes in 1967 (124,000 people). Those students were likely to be among the best-performing ones with only 12.2 percent (973 people) returning among them. After the end of the Korean War in 1953, the number of Korean students who moved to the U.S. increased constantly. However, those who left Korea to study abroad in the 1960s later returned so that brain drain turned to 'brain gain,' which was important for strengthening economic and social development.

Right after the Korean War, foreign diagnosis including the Nathan Report (Robert, 1952) and Tasca Report (Tasca, 1953) acknowledged that manpower was the greatest and sole resource of Korea and argued that a trained and skilled workforce expedite Korea's recovery and support sustainable economy. However, its pre-modern weak educational system was not able to turn those untapped human resources into valuable 'human capital' for development (Cho, 2010, pp. 65-66). Therefore, to create a vibrant economy, the country first needed to establish an educational system with modernized institutions of higher education. At the same 
Table 1.3 Changes in the vocational training system

\begin{tabular}{|c|c|c|c|}
\hline & $\begin{array}{l}\text { Economic } \\
\text { backgrounds }\end{array}$ & $\begin{array}{l}\text { Strategies for Skill } \\
\text { development }\end{array}$ & $\begin{array}{l}\text { Enactment and } \\
\text { revision of legislation }\end{array}$ \\
\hline $1960 \mathrm{~s}$ & $\begin{array}{ll}- & \text { 1st, 2nd EDP } \\
- & \text { Shift from } \\
\text { agriculture to light } \\
\text { industry } \\
- & \text { Rising demands for } \\
& \text { workers }\end{array}$ & $\begin{array}{ll}- & \text { Vocational high } \\
\text { schools } \\
-\quad \text { New vocational } \\
\text { training system } \\
-\quad \text { Vocational training } \\
\text { subsidy system }\end{array}$ & $\begin{array}{l}-\quad \text { Vocational } \\
\text { Training Act } \\
\text { (1967) }\end{array}$ \\
\hline $1970 \mathrm{~s}$ & $\begin{array}{ll}- & \text { 3rd, 4th EDP } \\
- & \text { Shift to HCI } \\
- & \text { Serious shortage of } \\
& \text { skilled workers } \\
- & \text { Unlimited supply } \\
& \text { of unskilled } \\
\text { workers from rural } \\
\text { to urban areas }\end{array}$ & 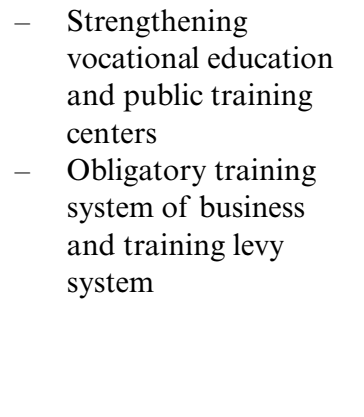 & $\begin{array}{ll}- & \text { Vocational } \\
\text { Training Special } \\
\text { Measures Act } \\
\text { (1974) } \\
-\quad \text { Basic Vocational } \\
\text { Training Act } \\
\text { (1976) } \\
-\quad \text { Vocational } \\
\text { Training } \\
\text { Promotion Fund } \\
\text { Act (1976) }\end{array}$ \\
\hline $1980 \mathrm{~s}$ & $\begin{array}{ll}- & \text { 5th, 6th EDP } \\
- & \text { Stabilization } \\
- & \text { Transition to high- } \\
& \text { tech industries } \\
- & \text { Falling demand for } \\
& \text { in-plant vocational } \\
& \text { training }\end{array}$ & 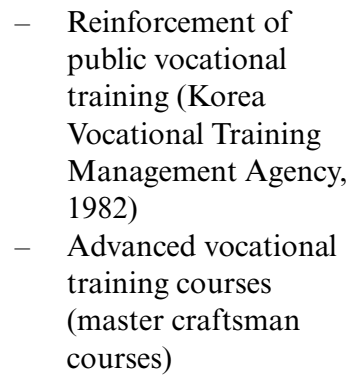 & $\begin{array}{l}\text { 4th amendment to } \\
\text { Basic Vocational } \\
\text { Training Act } \\
\text { (1987) }\end{array}$ \\
\hline $1990 \mathrm{~s}$ & $\begin{array}{ll}- & \text { Moderate } \\
\text { growth low and } \\
\text { unemployment } \\
-\quad \text { Economic crisis of } \\
1997 \\
-\quad \text { Growing need to } \\
\text { raise incumbent } \\
\text { workers' skill levels }\end{array}$ & $\begin{array}{ll}- & \text { Incentive for } \\
\text { voluntary vocational } \\
\text { training by employers } \\
\text { - } & \text { Training as social } \\
\text { safety net for } \\
\text { unemployed people }\end{array}$ & $\begin{array}{ll}- & \text { Employment } \\
\text { Insurance Act } \\
\text { (1995) } \\
- & \text { Workers } \\
\text { Vocational } \\
\text { Training } \\
\text { Promotion Act } \\
(1999)\end{array}$ \\
\hline $2000 \mathrm{~s}$ & $\begin{array}{ll}- & \text { Knowledge-based } \\
\text { global economy } \\
- & \text { Sluggish growth } \\
- & \text { Flexible labor } \\
& \text { market }\end{array}$ & $\begin{array}{l}\text { - Life-long vocational } \\
\text { training system } \\
-\quad \text { Strengthening of } \\
\text { training for vulnerable } \\
\text { groups }\end{array}$ & $\begin{array}{ll}- & \text { Workers } \\
\text { Vocational Skills } \\
\text { Development Act } \\
\text { (2004) }\end{array}$ \\
\hline
\end{tabular}

Source: Ra and Kang (2012). 
time, the government had to send brilliant students abroad for training and invite foreign experts to design and run the new system. Korea needed university professors with modern training to implement the desired changes in its higher education institutions.

To this end, the Korean and U.S. governments initiated the Seoul National University (SNU) Project. The U.S. government hired the University of Minnesota (UMN) to undertake this large-scale project. The consultants, American professors equipped with teaching and management experience in the U.S., resided in Korea, converting SNU into a more efficient American-model university. They supervised the design and construction of buildings and procured necessary equipment and research materials. Another important mission of the consultants was to deliver a modern American education to the selected Korean professors to expose them to frontier research, to legitimize their expertise, and to identify them as conduits for modern education (Cho, 2010, p. 37).

The program took place over six academic years, with the first class entering in 1955 and the last in 1960. The first phase involved the training of teaching staff at SNU's schools of medicine, agriculture, and engineering with veterinary medicine and nursing as subfields. The second phase worked to establish the School of Public Administration, which included recruiting or training its new faculty members. The UMN professors were contracted to develop new departments and choose the first faculty members who were immediately sent to UMN for training. Participants for the second phase came from the Korean government offices and from various universities in Korea. During the two phases of the SNU Project, 226 members of the SNU faculty studied at the University of Minnesota under the project (Cho, 2010, p. 67). ${ }^{7}$

Other than the SNU project, the USAID also operated a technical training program for Korea from 1954 to 1962, providing overseas training for 2,148 participants, of which 384 received training in public administration. Washington University and Peabody College under contracts with the USAID supported strengthening business administration education and teacher training, respectively. With support from the Rockefeller Foundation and the Ford Foundation, the World Bank, and the International Monetary Fund, Vanderbilt University ran training and scholarship programs for the Korean government officials from 1956 to 1970 (Cole et al., 2015).

By absorbing advanced knowledge and practices from the U.S., Korea created a critical mass of reform-minded academic elites who played

7 Fifty-seven professors in agriculture, 64 in engineering, 78 in medicine, and 27 in public administration were trained by this project. 
the role of priming active academic and political exchanges between the countries. The project also contributed to laying the grounds for liberal democracy and nation building of Korea.

KAIS was another key project that expedited active brain gain. While preparing industrial restructuring, the Korean government realized that the supply of high quality scientists and engineers was still very limited and that it was expensive to retain the specialists because most of them were educated and trained abroad. Meanwhile, the education programs at domestic universities focused more on theory than practical trainings. Industrial development invoked an urgent and mounting demand for domestic graduate education that would foster high quality brain workers well-versed in the technologies and skills that domestic industrial fields desperately needed.

Dr. Jeong Geun-mo, who was a Korean scientist in the U.S. and an alumni of the School of Public Administration at the Seoul National University, drafted a proposal for establishing a specialized graduate school in science and engineering, hoping to get support from the USAID. In March 1970, the Korean government reviewed the proposal to establish a graduate school in the Economic Trends Report Meeting, and the concrete plans for the school were designed by the Ministry of Science and Technology. The U.S. government dispatched a delegation to investigate the necessity of a new science and engineering graduate school in Korea. It was led by Frederic E. Terman, a former Vice President of Stanford University and the father of Silicon Valley. Based upon his investigation and recommendation, the Korea Advanced Institute of Science (KAIS) was established within the Seoul Research Development Park in Hong-neung in 1971. KAIS hired 40 professors and officially opened in 1973.

The school's first batch of 92 master's degree recipients in science and engineering graduated in 1975, and the resulting alumni eased the shortage of high-caliber scientists by forming the core mass of scientists and engineers in Korea (Hong, Jeon, and Kim, 2013, pp. 85-86). ${ }^{8}$ The new domestic institution with renewed equipment and competent faculty also contributed to relieving the problem of brain drain by reducing the

8 KAIS changed its name to KAIST in 1981 by merging with KIST (Korea Institute of Science and Technology). Even though these two institutions were separated in 1989, KAIST retained its name thereafter. KAIST graduates comprised $73 \%$ of the total doctorate degree recipients in Korean science and engineering sector in $1990.30 .6 \%$ of the KAIST graduates entered education sector, while $36.8 \%$ and $27.6 \%$ joined research institutions and industry, respectively. Also, $35 \%$ of KAIST's master's program graduates entered the industry sector to become the gatekeepers of new technology development at private companies (KAIST, 1992). 
outflow of advanced talent and recruiting outstanding Korean scientists working in foreign countries (Hwang and Kang, 2011, p. 44).

The newly established higher educational institutions such as SNU and KAIS became the engines boosting the Korean science and technology to the global level by replacing the old inactive graduate education with globally competitive American education and practice. Faculty members at both institutions were educated in the U.S. and disseminated a new wave of higher education in terms of teaching, evaluation, and laboratory systems to Korea's domestic academia. Furthermore, these institutions helped promote national innovation and brain gain, working as conduits that bridged the relatively small domestic society with the wide global communities.

During the period of its transformation from agricultural to industrial economy, Korea needed to learn to implement industrial technology on its own. ${ }^{9}$ Without being able to use technology independently, the country would be subordinate to other technologically superior countries, hindering self-reliant sustainable development. In the 1960s, a few higher educational institutions with little experience in modernized operation were insufficient to influence the industrialization of the economy. Furthermore, the domestic companies or industries were not capable of investing in research and development, not to mention implementing them. However, President Park Chung-hee had to promote heavy and defense industries due to the threat of North Korea and the planned withdrawal of the U.S. military from the peninsula in spite of the nascent capacities of industries and academia. The rising and urgent demands of advanced technology compelled the government to come up with an innovative measure to resolve the impasse.

Companies in industrial sectors such as chemical, steel, machinery, and the related ones had to improve their own capacity to use the relevant technologies by assimilating the existing advanced technologies. For both government and companies, the technology of these sectors reaching the global level was a desperate issue because the sunk cost of investment for these sectors was already heavy, and they were targeted as strategic export sectors. That is, the companies in these sectors had to compete and survive in the global market. Thus, the government encouraged big businesses to acquire the necessary foreign capital and technology. At the same time, the Korean government recognized the need to establish specialized research institutes in order to actively accommodate the increasing demands for

9 The industrial structure in 1961 showed $40.2 \%$ of the primary industry and $15.2 \%$ of the second industry. The contribution of the second industry to the Gross National Product (GNP) was only 13\% (Hwang and Kang, 2011, p. 52). 
various technologies (Hwang and Kang, 2011, p. 55). To meet such needs, the Korea Institute of Science and Technology (KIST) was established in 1966 as the first modern, comprehensive applied research institute in Korea with the support of the U.S. government after a summit meeting in the previous year. It provided the fundamentals for science and technology development and self-reliance by developing domestic R\&D capabilities. KIST played a central role in adoption, absorption, and assimilation of modern technology, improving imported technologies and establishing self-reliance of technology development (Hwang and Kang, 2011, p. 84).

KIST ran an innovative operation at the time. By special enactment, the institute was guaranteed autonomy and independence with very limited interference from the government despite public financial support. It could also recruit outstanding scientists from abroad with exceptionally high compensation and initiate very dynamic and flexible research activities, which would not have been possible as a government-attached institute. The researcher-friendly conditions were a prerequisite in bringing back highly qualified science and technology manpower from abroad despite unfavorable political and academic situations (Hwang and Kang, 2011, pp. 59-60).

The Korea Development Institute (KDI) was another U.S. governmentaided project, sharing similar features as the KIST project. KDI was established as a comprehensive economic policy think tank and was legitimated by a special act, guaranteeing its autonomy and public financial support. Establishment of KDI contributed to 'brain gain' and effective planning of national development. Both of these innovative institutions had devoted and consistent top management leadership from the preparation stage, which was also fully sponsored by a special support from the president.

Similar government-funded research institutions (GRIs) were copied and established, spreading to every field and sector of the Korean society. They supported the government in planning, implementing, and monitoring policies and worked as brain reservoirs in each field. Governmentfunded research institutes provided an opportunity to induce many Korean scientists and specialists staying abroad to return. They contributed to the localization of advanced technologies and took a leading role in modern science and technology development in Korea (Hwang and Kang, 2011).

KIST, KDI, and other government-funded research institutes helped reduce the technology and knowledge gaps with the advanced countries by enhancing the overall domestic level of science and technology and building policy capacities. Especially when universities and business were incapable of renovating the country with new ideas or technology, GRIs supported the government in initiating many projects to expedite socioeconomic development as key players in the national innovation system (NIS). 
Overall, the newly established modern universities and governmentfunded research institutes primed a virtuous cycle of brain gain. By replacing inactive and inferior graduate education with globally competitive American education and practices, the modernized and global higher education institutions worked as engines for upgrading Korea's level of science and technology. The repatriation of Korean intellectuals to the universities and institutes contributed to the weakening of the Confucian culture that made light of technicians and hindered industrialization. This led to a new national innovation system that allowed scientists and engineers to rise quickly to the top rank of Korea's sociopolitical strata. At the same time, the scientific planning and monitoring by highly qualified professional researchers in policymaking processes strengthened the capacity of the Korean government and its officials. In turn, competitive rewards for foreign-trained scholars and researchers encouraged young students to invest more in their educational attainment to contribute to the brain gain. In sum, those institutions contributed to promoting national innovation and effective brain gain, working as conduits that bridged Korea's relatively small academic and research society with the global communities.

For maintaining sustainable growth and development, domestic enterprises have to compete and survive in the global market through innovation. In the course of Korea's economic development, Korea's government as well as domestic enterprises made many ambitious investments by taking risks and responsibilities and were rewarded with fruitful outcomes. Particularly during the early stage of industrialization in the 1960s, the Korean government brought in large-scale foreign loans and allocated them to a set of selected industries for investment purposes, leading to a massive importation of foreign capital goods and turnkey plants. Due to the restrictive policies on inviting foreign investment, a major source of technological learning was the OEM (original equipment manufacturing) production arrangement for light industries. In the case of heavy industries, businesses reverse-engineered imported capital goods to acquire the relevant technologies. The government encouraged these channels of technology learning by enacting the Science and Technology Promotion Act and the Science Education Act in 1967. This is why Foreign Direct Investment (FDI) played a less important role in Korea in capital and technology acquisition than in other developing countries (Chung, 2011; Kim, L., 1997).

When the economy shifted from light industries to heavy and chemical industries in the 1970s, the government arranged massive investment projects to build facilities for those new industries. The turnkey plants for the chemical industry and foreign licensing for heavy machinery, which were informal channels of acquiring technologies, required Koreans to 
learn to assimilate and apply the transferred technologies. The government helped private enterprises in picking up knowledge by establishing government research institutions (GRIs) and linking them with the relevant industries. The Korea Institute of Machinery and Metals, the Electronics and Telecommunications Research Institute, the Korea Research Institute of Chemical Technology, the Korea Research Institute of Standards and Science, the Korea Institute for Energy Research, and the Korea Ocean $\mathrm{R} \& \mathrm{D}$ Institute guided the technological learning of private enterprises (Chung, 2011; Kim, L., 1997). Starting with technology assimilation, the GRIs developed and commercialized many technologies, including the following (Hwang and Kang, 2011, pp. 84-85):

(a) KIST: polyester film, semiconductor lead frame technology, computerizing technology.

(b) Korea Institute of Machinery and Materials: automation system, software and design technology used for CAD/CAM, etc.

(c) Korea Chemical Technology Research Institute: antibiotic substances, advanced chemical materials, etc.

(d) Electronics and Telecommunications Research Institute: domestic computers, 4M DRAM semiconductors, digital switching system called time-division exchange (TDX) series.

(e) Korea Atomic Energy Research Institute: localization of nuclear fuel, Korean nuclear reactor.

As the Korean economy further developed and became more open to global competition in the 1980s, technology demanded became more sophisticated and advanced so that Korea faced a fundamental limitation in fostering development through assimilation. The Korean government responded to this change by shifting the policy focus from 'technology learning' to 'technology development.' The government implemented various measures to promote and facilitate private R\&D activities including tax incentives, financial assistance, procurement, and other promotional actions. The government also employed a new $R \& D$ investment strategy to provide private enterprises with opportunities to cooperate with the public sector. The Ministry of Science and Technology launched the National R\&D Program in 1982, and other government initiatives such as the 'Industrial Base Technology Development Program' by the Ministry of Commerce, Industry, and Energy, and the 'Information and Communication Technology Development Program' by the Ministry of Information and Communication followed among others.

The private sector increased their investment in $\mathrm{R} \& \mathrm{D}$, surpassing that of the government since 1981 and now accounting for three-quarters of the 
total national R\&D investment. Besides the active role of the government in promoting private $\mathrm{R} \& \mathrm{D}$, it was the competitive global market placing huge pressures on Korean enterprises, which induced more investment in $\mathrm{R} \& \mathrm{D}$ on their own to keep up with such competition. The outwardlooking and export-oriented development strategy of the Korean economy kept businesses alert to rapidly changing technologies and the global market (Chung, 2011; Kim, L., 1997).

\section{NEW CHALLENGES}

The above positive features of Korea's human capital accumulation have continued until recently. Korea has acquired abundant human capital for the national workforce as well as for research and development through its expansion from basic to higher education. Korea's average years of schooling among labor market entrants is the second highest in the world. The number of researchers per inhabitant is fourth in the world behind Finland, Denmark and Singapore. In terms of the size of R\&D investment, Korea has spent as much as 4.36 percent of its GDP, which is also the highest in the world. Therefore, the quantitative expansion of research and development seems to be mature in Korea.

However, Korea has recently faced new challenges in terms of human capital accumulation. Despite the rapid quantitative expansion in R\&D, there is a growing concern about the quality of research outcomes in Korea. National innovation should be linked with economic vitality, and research and development plays a critical role for the link. However, the proclaimed conversion of development strategy from 'catching-up' or 'fast-follower' to 'creation' or 'first-mover' at the beginning of the knowledge-based global economy does not seem to have led to much tangible impacts on the Korean economy.

The R\&D spending is heavily dominated by the in-house activities of a few large business groups, emphasizing applied research with a disregard for basic research and focusing on 'development' over research. Furthermore, the R\&D of small-and-medium-sized companies is mostly inactive. The lack of quality in $R \& D$ measures may be related to these unbalanced R\&D strategies and the capacity of the key economic players. It also carries the problems of insufficient focus on service sector R\&D and the lack of international research collaboration. Thus, Korea's R\&D strategy needs to be re-examined and re-oriented to maintain its sustainable development.

The current Korean schooling system has been criticized for focusing too much on test scores and rote learning at the expense of nurturing creativity 
and character skills, which is an obstacle to achieving a 'creative economy' (King and Rogers, 2014; Connell, 2014; Kim, L., 2001). Furthermore, a recent problem concerns the mismatch between the contents and quality of Korea's higher education and the contemporary technological progress. Indeed, the returns to college education are too different across universities, and the returns are negative for the bottom 20 percent college graduates, which we term an 'education bubble.' This is also an issue of the 'quality' of human capital rather than the quantity in the dimension of schooling similar to the R\&D dimension.

According to the IMF's projection, Korea's potential growth rate is forecasted to stay around 3.0 percent per year between 2008 and 2050 (IMF, 2006). A diminishing labor supply resulting from low fertility rates and lagging productivity in the service sector reinforce the gloomy forecasts. Exports, which accelerated growth until now, have been less effective for boosting domestic consumption and job creation not only for Korea but also for the entire globe (OECD, 2014a). Thus, it is an important moment for Korea to reconsider its human capital policy to sustain its growth.

In the following chapters, we address the success and failures of Korea's accumulation of human capital in relation to the above new challenges in more detail and draw substantive policy implications for human capital development. This will provide a significant guideline for human capital strategy not only in Korea but also in many developing and developed countries. 